\title{
Designing Open-Ended Instruction for Improving Elementary School Student's Critical Thinking Ability
}

\author{
Ludiana Fitriyah, Siti Maghfirotun Amin, Tatag Yuli Eko Siswono \\ Post Graduate Program of Elementary Education Department \\ State University of Surabaya \\ Surabaya, Indonesia
}

\begin{abstract}
The ability to think critically is an important ability that elementary school students must have. The ability to think critically helps students make the right decisions about what to believe and what actions to take in the present or in the future. The ability to think critically can be developed by an open-ended approach to learning mathematics. The open-ended approach uses open-ended problems that have more than one correct answer and various ways of solving. Open-ended problem is expected to motivate students to find solutions independently so that in the process students' critical thinking ability will increase. This study aims to describe the process of developing mathematics learning tools using an open-ended approach for fourth-grade elementary school students to improve critical thinking ability. The learning tools development model consists of 3 phases, namely preliminary research (needs and context analysis, review of literature, development of a conceptual or theoretical framework for the study), prototyping phase (syllabus design, lesson plans, worksheets and expert validation) and assessment phase (limited trials). The trial in this study used a one-group pretest-posttest design with the research subjects of 19 fourth-grade students at Kedungdoro I/306 elementary school. The data collection technique used a device validation sheet, an observation sheet for the implementation of lesson plans and student activities, a student response questionnaire and a critical thinking ability test. The data obtained were analyzed using the average score which was converted according to the defined categories.
\end{abstract}

The results show that the learning tools developed are valid based on the assessment of the two validators, practical based on the implementation of the lesson plan and student activities in the "very good" category, and effective based on the responses of students who are in the "strong" category and student's critical thinking ability that significantly increased with medium category based on paired sample t-test and N-Gain analysis.

Keywords:- Development of Learning Tools, Open-Ended, Critical Thinking.

\section{INTRODUCTION}

Critical thinking is one of the fundamental abilities that students must have to face global competition in the 21st century. Ennis defines critical thinking as a process where individuals make decisions about what to believe and what actions to take [1]. Good critical thinking ability, when applied properly, will help a person to make more realistic and accurate judgments related to abilities, interests, and thinking processes [2]. According to Critical Thinking Cooperation, critical thinking is a higher ability than memorizing. Students who have critical thinking abilities are encouraged to think independently, question hypotheses, analyze, and synthesize events in order to go a step further by developing new hypotheses and testing them against existing facts. Critical thinking will increase creativity and improve how to use and manage time. Critical thinking not only describes the ability to think according to the rules of logic and probability, but also the ability to apply these skills in real terms [3].

Critical thinking is an ability that can be developed [4]. As one of the important abilities students must possess, critical thinking must be developed early on. There are two different methods of developing critical thinking ability. Some researchers believe that critical thinking ability can only be taught separately [5] while some other researchers believe that critical thinking ability can be integrated into learning in schools [6]. Mathematics is one of the subjects that can develop critical thinking ability [7]. Critical thinking ability in mathematics is critical thinking processes related to mathematical knowledge, mathematical reasoning, and mathematical proof in solving mathematical problems[8]. Mathematical learning that can develop critical thinking skills requires complex mathematical problems that can encourage higher-order thinking skills[9]. High-level math problems that involve thinking, analysis, synthesis can stimulate students' critical thinking skills. Thus, complex problem-solving activities will increase students' understanding and be able to apply the knowledge that is built up in new situations.

The reality is found in the field, mathematics learning in schools does not encourage students to think critically. Based on the observations of researchers, the teacher is more dominant using the lecture method and assigns tasks to students to work on questions from textbooks and worksheets that are routine and closed. Most teachers only 
use textbooks and involve low-level thinking skills such as memorizing facts [10]. Examples of problems in mathematics, the area of geometric plane figure's material in books given to students are as follows.

"The floor of Faiz's room is a rectangle with a length of $4 \mathrm{~m}$ and a width of $3 \mathrm{~m}$. Find the area of Faiz's room!" [11].

Most students can solve routine problems by entering into a formula that they already know, but when students are given problems with other types they find it difficult. Most of them can only do routine problems like the example above or questions of the same type as exemplified by their teacher. This results in the formation of the thought that is a problem there is only one solution and one correct answer, namely the method and answer given by their teacher. This results in less development of students' critical thinking skills because they are not used to finding their own ways to solve a problem or problem they face based on the knowledge or information they have. In this regard, Sutawijaya argues that the orientation or ultimate goal of routine questions given to students is the correct answer from students so that teachers tend to lack or even pay attention to the process that students go through to get these answers. This certainly does not encourage students to think critically because critical thinking is obtained from the process of students solving a problem. Siswono also argues that student books or worksheets in the school environment tend to emphasize mastery of concepts without giving students the freedom to think independently so that they do not encourage the development of students' critical thinking ability [13]. Therefore, learning tools that cover complex problems are needed to support the development of mathematics learning to improve students' critical thinking skills in the classroom. Critical thinking skills in mathematics are closely related to problem-solving in mathematics. The application of open-ended mathematics problems and contextual problems will challenge students to solve problems to encourage students to think mathematically so that students' critical thinking skills will also increase.

Open-ended problem solving is based on research conducted by Shimada S. which is called "The Open-ended Approach". This approach facilitates students with experiences in discovering something new through the process [14]. The open-ended approach uses open-ended problems that allow students to find more than one correct answer in various ways. Learning mathematics with openended problems provides opportunities for students to use their skills to seek information and connect with relevant concepts and independently find solutions to problems. Indirectly, students are training themselves to think critically so that it triggers their ability to find solutions to the problems they face.

In order to carry out learning with an open-ended approach properly and in accordance with students' abilities, good learning tools are needed as well. This study aims to develop an open-ended learning tool on the circumference and area of the plane figures (rectangle, square, and triangle). The material will be taught to grade IV elementary school students who are focused on the selected basic competencies. The benefit of this research is the availability of mathematics learning tools with an openended approach to the circumference and area of the plane figures that can be used by schools, especially teachers and students to improve the critical thinking ability of 4th-grade elementary school students.

In this study, learning tools with an open-ended approach will be developed for mathematics subjects. The difference between this learning device and the learning device in other previously made research is in the material used, namely the circumference and area of the plane figures (square, rectangle, and triangle) as well as the questions or open-ended problems used in learning.

\section{METHOD}

This study is development research that aims to develop products in the form of learning tools (syllabus, lesson plans, and worksheets). The development model used is the Plomp development model which consists of 3 phases, namely preliminary research, prototyping phase, and assessment phase [15]. The quality of learning tools is seen from the aspects of validity, practicality, and effectiveness [16]. The instruments used in data collection are as follows.

\begin{tabular}{|c|c|c|c|}
\hline $\begin{array}{c}\text { Rated } \\
\text { aspect }\end{array}$ & Instrument & Data collected & $\begin{array}{c}\text { Respondent } \\
\text { S }\end{array}$ \\
\hline Validity & $\begin{array}{c}\text { Validation } \\
\text { sheet }\end{array}$ & $\begin{array}{c}\text { Validity of } \\
\text { syllabus, } \\
\text { lesson plan, } \\
\text { and } \\
\text { whorksheet }\end{array}$ & $\begin{array}{c}\text { Experts } \\
\text { (Validator) }\end{array}$ \\
\hline Practicality & $\begin{array}{c}\text { Observation } \\
\text { sheet }\end{array}$ & $\begin{array}{c}\text { Implementatio } \\
\text { n of lesson } \\
\text { plans and } \\
\text { student } \\
\text { activities }\end{array}$ & $\begin{array}{c}\text { Observer } \\
\text { (teacher) }\end{array}$ \\
\hline $\begin{array}{c}\text { Effectivene } \\
\text { ss }\end{array}$ & $\begin{array}{c}\text { Questionnair } \\
\text { e }\end{array}$ & $\begin{array}{c}\text { Student } \\
\text { response }\end{array}$ & $\begin{array}{c}\text { Test } \\
\text { subjects } \\
\text { (students) }\end{array}$ \\
\hline & Test & $\begin{array}{c}\text { Critical } \\
\text { thinking } \\
\text { ability test } \\
\text { score }\end{array}$ & $\begin{array}{c}\text { Test } \\
\text { subjects } \\
\text { (students) }\end{array}$ \\
\hline & & & \\
\hline
\end{tabular}

Table 1

Analysis of the validity of the learning device is done by converting the average value of the validation results according to the criticism and suggestions of the two validators. The learning tools were tested with one-group pretest and posttest design on 19 of fourth-grade students of Kedungdoro I / 306 elementary school for the 2019/2020 academic year in order to determine the practicality and effectiveness of learning. Analysis of the practicality of learning tools is obtained from the average results of the implementation of the lesson plans and student activities 
which are converted into predefined categories. The effectiveness of learning tools is seen from the results of the students' critical thinking skills test and student responses to the learning that has been done.

\section{RESULT AND DISCUSSION}

The development of tools in this study uses the Plomp development model which consists of three phases, namely preliminary research, prototype, and assessment. In the preliminary research phase, needs and context analyses were carried out, theoretical studies, and the creation of a learning framework. In the prototyping phase preparation of learning tools (syllabus, lesson plans, and student worksheets) is carried out and the validity of the learning tools is tested.

\section{A. Preliminary Research}

From the results of the needs and context analysis, it is found that the fundamental problem is the lack of habituation in giving questions that can improve students critical thinking ability in learning activities. This is because there are problems with the teacher in preparing appropriate learning tools to train students' critical thinking ability. Based on the analysis of needs and context, the researcher examines the theory in order to create a theoretical framework for learning that can improve students' critical thinking ability. The curriculum used in learning in class IV Kedungdoro I/ 306 elementary school is the "Kurikulum 2013". The material used in research is the perimeter and area of plane figures with demands of basic competencies "solving problems related to the perimeter and area of squares, rectangles, and triangles including involving squares with square roots".

The learning with an open-ended approach in this study using the following steps.

\begin{tabular}{|c|c|c|}
\hline Main steps & Teacher activities & Student activities \\
\hline Orientation & $\begin{array}{l}\text { Describe learning objectives and motivate } \\
\text { students to be involved in problem solving } \\
\text { activities using questions related to students' } \\
\text { daily lives. }\end{array}$ & $\begin{array}{l}\text { Listening to the teacher's explanation, asking } \\
\text { and answering questions with the teacher or } \\
\text { working on questions if there are questions } \\
\text { asked by students or questions given by the } \\
\text { teacher. }\end{array}$ \\
\hline $\begin{array}{l}\text { Preparation of solving open- } \\
\text { ended problems }\end{array}$ & $\begin{array}{l}\text { Provide a general explanation of the } \\
\text { material to be studied by students (the } \\
\text { purpose of this activity is to equip students } \\
\text { for the next step, namely solving open-ended } \\
\text { problems.) } \\
\text { - Instruct students to form groups } \\
\text { Presenting open questions. }\end{array}$ & $\begin{array}{l}\text { Listening to the teacher's explanation, forming } \\
\text { groups, and receiving student worksheet. }\end{array}$ \\
\hline $\begin{array}{l}\text { Group discussion about } \\
\text { solving open-ended problems }\end{array}$ & Guiding students in group discussions. & $\begin{array}{l}\text { Complete group assignments in discussion with } \\
\text { teacher guidance. }\end{array}$ \\
\hline $\begin{array}{l}\text { Presentation of group } \\
\text { discussion results }\end{array}$ & $\begin{array}{l}\text { Help determine group members who will } \\
\text { represent the group to present the results of } \\
\text { the group's discussion and guide the } \\
\text { discussion in class. }\end{array}$ & $\begin{array}{l}\text { Displaying the results of their group } \\
\text { discussions, providing responses or giving } \\
\text { questions to the group presenting the results of } \\
\text { their group discussions. }\end{array}$ \\
\hline Conclude & $\begin{array}{l}\text { Draw conclusions with students about the } \\
\text { important points obtained from the learning } \\
\text { that has been done and provide questions or } \\
\text { feedback to get the expected important } \\
\text { points. }\end{array}$ & Draw conclusions guided by the teacher. \\
\hline
\end{tabular}

Table 2:- Steps of learning with an open-ended approach

\section{B. Prototyping Phase}

The second phase is prototyping. In this phase, the preparation of learning tools (syllabus, lesson plans, and student worksheets) is carried out and the validity of the learning tools is tested. The syllabus and lesson plans developed are adjusted to the steps of the open-ended approach, while the worksheets developed contain openended problems that must be solved by students. The device that has been designed is then called a draft prototype. The prototype draft was then validated by two validator experts in mathematics using a validation sheet. The scores given by the two validators are then averaged and compared with the device validation score category. Learning devices are declared valid if at least they are in the "good" category. The level of agreement between the two validators on the assessment of learning devices is known from the Percentage of Agreement (PA). The learning device validation score is declared reliable if the percentage is $\geq 75 \%$. The results of the learning tools validation in this study are presented in the following table. 
ISSN No:-2456-2165

\begin{tabular}{|c|c|c|c|c|}
\hline Learning Tools & Score Validation & Category & Information & PA \\
\hline Syllabus & 3,10 & Good & Good & Valid \\
\hline Lesson plan & 3,36 & Good & Valid & $96 \%$ \\
\hline Student worksheet & 3,13 & $93 \%$ \\
\hline
\end{tabular}

Table 3:- The result of learning tools validation

Based on the table 3 above, the learning device is declared valid and reliable. The final result of this phase is prototype 1 .

\section{Prototyping Phase}

The third phase is the assessment phase. In this phase, a trial was conducted to determine the practicality and effectiveness of the learning tools. The model used in testing the device was the one-group pretest-posttest design.

Learning tools are said to be "practical" seen from 2 aspects, namely the implementation of lesson plans in learning and student activities. These two aspects were assessed through limited trial activities carried out on 19 grade IV students of Kedungdoro I / 306 Elementary school for the 2019/2020 school year in December 2019 using observation sheets filled in by two observers. The scores given by the two observers on the implementation of the lesson plans were then analyzed to find the percentage of the implementation of the lesson plans. Student activity was also observed by two observers. The observed student activities included 8 aspects of student activities related to the Open-Ended Approach steps, namely (1) listening to the teacher's explanation when delivering the material and learning objectives; (2) question and answer with the teacher; (3) forming small groups in an orderly manner; (4) cooperate with a group of friends in completing group assignments; (5) participate in group presentation activities; (6) participate in discussing problem-solving with the teacher; (7) involved in making conclusions on the results of problem-solving; and (8) doing assignments/exercises given by the teacher. Based on the results of observations, at the first meeting, most students found it difficult to solve open-ended problems in student worksheets. This is in accordance with research conducted by Parwati which states that the first time they faced open questions, $60 \%$ of students did not understand the commands in the questions and some even said that the questions were incomplete [17]. Some students also appear passive and rely on other students to complete group assignments because they find it difficult to face the open questions presented. In dealing with this, the teacher in the learning process guides students to understand open questions and find answers to open questions given through group discussion activities. At the second and third meetings, students are getting used to and can adjust to open-ended learning. Another thing that the researcher found in learning was that students quickly felt satisfied with the answers they found, so they tended to stop looking for alternative answers so that almost every group had the same answer. To overcome this, the teacher makes a rule that each group that has a correct answer that is different from the other groups will get double points. With such motivation, students are excited again to look for other answers that would be different from other groups. The assessment given by the observer is written on the student activity observation sheet with a score range of 1-4. The scores given by two observers are then analyzed to obtain the percentage of student activity. The results of the implementation of the lesson plan and student activities in the research trial are presented in the following table.

\begin{tabular}{|c|c|c|c|c|}
\hline Meeting & $\begin{array}{c}\text { Implementation of the Lesson } \\
\text { Plan }\end{array}$ & Category & Student Activities & Category \\
\hline Meeting 1 & $90 \%$ & Very good & $82 \%$ & Very good \\
\hline Meeting 2 & $93 \%$ & Very good & $88 \%$ & Very good \\
\hline Meeting 3 & $94 \%$ & Very good & $88 \%$ & Very good \\
\hline
\end{tabular}

Table 4:- The result of lesson plan implementation and student activities

From the table 4, it can be concluded that the implementation of the lesson plans and student activities in learning are in the "very good" category. From the results of the analysis above, it can be concluded that the learning tools have fulfilled the practical aspects.

The effectiveness of learning tools can be seen from the results of student response questionnaires and an increase in students' critical thinking ability. Students' responses and opinions regarding the learning process that have been implemented are an understanding of student responses. Student responses are known from the results of the questionnaire given after learning is completed. The student response questionnaire in this study consisted of 10 positive statements and 10 negative statements related to the learning that had been implemented. Students put a check mark $(\sqrt{ })$ in the column "strongly agree", "agree", "disagree" or "disagree" in accordance with student opinions about the learning that has been implemented. The scores obtained from the student response questionnaire were analyzed to obtain the percentage of student response scores. Based on the results of the analysis, the percentage of student response scores to leraning with an open-ended approach is $78 \%$ and is in the "strong" category. 
In addition to student responses, learning tools are said to be effective if there is a significant increase in students' critical thinking ability. Students' critical thinking ability were measured using critical thinking ability tests. The critical thinking ability test used in this study was a description of 3 questions. This test was given to 19 class
IV students before being given treatment (pretest) and after being given treatment (posttest). The pretest and posttest questions are different but have the same level. The question indicators are derived from predetermined basic competencies. The indicators are as follow.

\begin{tabular}{|c|c|c|}
\hline Basic competencies & Question indicators & Question number \\
\hline \multirow{3}{*}{$\begin{array}{l}\text { Solving problems related to the perimeter and } \\
\text { area of squares, rectangles, and triangles } \\
\text { including involving squares with square roots. }\end{array}$} & $\begin{array}{l}\text { Solve the open-ended problem related to } \\
\text { perimeter and area of the rectangle }\end{array}$ & $\begin{array}{l}1(\mathrm{a}) \\
1(\mathrm{~b}) \\
\end{array}$ \\
\hline & $\begin{array}{l}\text { Solve the open-ended problem related to } \\
\text { perimeter and area of squares and } \\
\text { rectangle }\end{array}$ & $\begin{array}{l}2(\mathrm{a}) \\
2(\mathrm{~b}) \\
2(\mathrm{c}) \\
2(\mathrm{~d})\end{array}$ \\
\hline & $\begin{array}{l}\text { Solve the open-ended problem related to } \\
\text { perimeter and area of triangles and } \\
\text { rectangles }\end{array}$ & 3 \\
\hline
\end{tabular}

Table 5:- Indicators of Critical Thinking Ability Test

Every answer given by students becomes a benchmark for students' critical thinking ability. This is indicated by the acquisition of scores on each number with indicators derived from the five groups of critical thinking ability according to Ennis as follows.

\begin{tabular}{|c|c|c|c|}
\hline Critical Thinking Ability & Critical Thinking Ability Indicator & Number Question & Score \\
\hline $\begin{array}{ll}\text { - } & \text { Perform basic classification } \\
\text { - } & \text { Establish basic skills } \\
\text { - } & \text { Making Conclusions }\end{array}$ & $\begin{array}{l}\text { - Answer questions that contain } \\
\text { challenges. } \\
\text { - Considering the results of } \\
\text { observations. } \\
\text { - Make consideration of decisions. }\end{array}$ & $1(\mathrm{a})$ & $\begin{array}{l}1 \\
1 \\
1\end{array}$ \\
\hline $\begin{array}{ll}- & \text { Perform basic classification } \\
\text { - } & \text { Establish basic skills } \\
\text { - } & \text { Making Conclusions } \\
& \text { Explain further }\end{array}$ & $\begin{array}{l}\text { - Answer questions that contain } \\
\text { challenges. } \\
\text { - Considering the results of } \\
\text { observations. } \\
\text { - Make consideration of decisions. } \\
\text { - Identify assumptions. }\end{array}$ & $\begin{array}{l}2 \text { (a) } \\
2 \text { (b) } \\
2 \text { (c) } \\
2 \text { (d) }\end{array}$ & $\begin{array}{l}1 \\
1 \\
1 \\
1\end{array}$ \\
\hline $\begin{array}{l}\text { - Establish basic skills } \\
\text { - Establish basic skills } \\
\text { - Develop techniques and } \\
\text { strategies }\end{array}$ & $\begin{array}{l}\text { - Considering the results of } \\
\text { observations. } \\
\text { - Answer questions that contain } \\
\text { challenges. } \\
\text { - Make a decision about an action. }\end{array}$ & 3 & $\begin{array}{l}1 \\
1 \\
1\end{array}$ \\
\hline
\end{tabular}

Table 6:- Score's indicator of critical thinking ability test

Before being tested, the pretest and posttest questions were validated by two validators. The validation result is that the pretest and posttest questions are declared valid and reliabel so it can be used in limited trials. The result of the trial is as follow.

\begin{tabular}{|c|c|c|}
\hline \multirow{2}{*}{ Total respondens } & \multicolumn{2}{|c|}{ Average Score } \\
\cline { 2 - 3 } & Pretest & Posttest \\
\hline 19 & 39 & 62 \\
\hline
\end{tabular}

Table 7:- Result of pretest and posttest

Based on the data in the table 7, there is an increase in the class average score between the pretest and posttest. The average grade for the pre-test score was 39 while for the post-test was 62 . To find out whether the increase in the class average score at the pretest and posttest was the effect of the application of learning tools with an open-ended approach, a paired sample t-test was carried out. Before conducting the paired sample t-test, the data normality test was conducted first. Because the sample used is small, the Shapiro Wilk normality test is used. Based on the Shapiro Wilk normality test using the IBM SPSS Statistic 25 application, the sig. the pretest value is 0.21 and the value of sig. the posttest value is 0.13. Based on these calculations, the results of the sig.> 0.05 so that the pretest and posttest data are declared to be normally distributed. Because the data were normally distributed, then the analysis was carried out using the paired sample t-test using the IBM SPSS Statistic 25 application. The results of the paired sample t-test showed a sig. (2-tailed) value of 0.000002 , so it can be concluded that there is a significant increase between the pretest and posttest results. To determine the categories of increasing students' critical thinking ability, the pretest and posttest data were analyzed using the N-Gain formula. The results of the N-Gain analysis showed that 2 students obtained an $\mathrm{N}$-Gain value 
of 0.00 or did not experience an increase, 2 students obtained an $\mathrm{N}-$ Gain value of 0.1 and were in the "low" category, 14 students obtained $\mathrm{N}-$ Gain in the range 0,33 0.67 and in the "medium" category and 1 student received $\mathrm{N}-$ Gain 1 and in the "high" category. The average N-gain obtained is 0.37 and it is in the "medium" category. Based on the analysis of student responses who are in the "strong" category and an increase in students' critical thinking skills significantly in the "medium" category, it can be concluded that the learning tools developed in this study have fulfilled the effectiveness aspect.

\section{ACKNOWLEDGMENT}

The conclusion of this study is (1) the learning tools with an open-ended approach on plane figure's perimeter and areas gone through 3 development phases according to the Plomp development model, that consist of preliminary research, prototyping, and assessment. (2) the validity of learning tools with an open-ended approach declared valid by the assessment of two validators. The learning tools with an open-ended approach is practical and effective for improving students' thinking skills based on the results of limited trials on fourth-grade students of Kedungdoro I/306 elementary school. Practical based on the assessment of the lesson plan implementation by the observer and student activities that are in the "very good" category. Effective based on the responses of students who are in the "strong" category and student's critical thinking ability that significantly increased with medium category based on paired sample t-test and N-Gain analysis.

To be more perfect, learning tools with an open-ended approach can be tested on more respondents by paying attention to the time allocation in their application. Based on these conclusions, the teacher is advised to apply openended learning tools to improve the critical thinking ability of the elementary school, especially fourth-grade students.

\section{REFERENCES}

[1]. Yildiz, "The Factors Affacting Techno-Pedagogical Competencies and Critical Thinking Skills of Preservice Mathematics Teacher", Malaysian Online Journal of Educational Sciences, vol. 5, 2017, pp. 6681.

[2]. Cottrell. S, Critical Thinking Developing Effective Analysis and Argument. New York:Macmillan Publisher, 2011.

[3]. Richard, W. Paul and Linda Elder, Critical Thinking. New Jersey: Financial Times Prentice Hall, 2002.

[4]. Aizikovitsh, E. and Amit, M, "Evaluating an Infusion Approach to the Teaching of Critical Thinking Skills Through Mathematics", Procedia-Social and Behavioral Sciences, vol. 2 (1), 2010, pp. 3818-3822.

[5]. Lipman, M., Thinking Skills Fostered by Philosophy for Children. In J.W. Segal, S.F. Chipman,dan R. Glaser (Eds.), Thinking and learning skills, pp. 83108. Hillsdale, NJ: Lawrence Erlbaum Associates, 1985
[6]. Swartz. R, Infusing Critical and Creative Thinking into Content Instruction, In A.L. Costa (Ed.).Developing Minds: A Resource Book for Teaching Thinking, 3rd edition. Alexandria, VA: Association for Supervision and Curriculum Development, 2001

[7]. Rajendran, N.S. Teaching and Acquiring Higher Order Thinking Skills: Theory and Practice. Tanjong Malim, Perak: Penerbit Universiti Pendidikan Sultan Idris, 2010.

[8]. Krulik, S. and Rudnick, J.A, The New Sourcebook for Teaching Reasoning and Problem Solving in Elementary School. Needham Heights: Allyn dan Bacon, 1995.

[9]. Henningsen, M. and Stein, M.K, "Mathematical Tasks and Student Cognition: Classroom-based Factors that Support and Inhibit High-level Mathematical Thinking and Reasoning”. Journal for Research in Mathematics Education, vol. 25(5), 1997, pp. 524549.

[10]. Tobin, K. \& Gallagher, J.J," Target students in the science classroom", Journal of Research inScience Teaching, 1987 vol. 24(1), pp 1-75.

[11]. Nuharini, D \&Priyanto, S, Mari Belajar Matematika: Pendidikan Matematika untuk SD/MI Kelas IV, Buku Guru.CV Usaha Makmur: Surakarta, 2016.

[12]. Hudoyo \& Sutawijaya. Pendidikan Matematika I. Jakarta: Dirjen Dikti Depdiknas, 1998.

[13]. Siswono T.Y.E, Pembelajaran Matematika Berbasis Pengajuan dan Pemecahan Masalah. Bandung:PT. Remaja Rosdakarya, 2018.

[14]. Shimada S., The Significance of an Open-Ended Approach in Shimada, S. \& Becker, J.P. (Ed). The Open-Ended Approach. A New Proposal for Teach-Ing Mathematics, NCTM, Reston, 1997

[15]. Plomp, Tjeerd, Educational Design Research: An Introduction in Tjeerd Plomp dan Nienke Nieveen (Ed). An Introduction to educational design research. Enschede: SLO Netherlands Institute for Curriculum Development, 2010

[16]. Nieveen, N. (1999). Prototype to Reach Product Quality in Van den Akker, J., Branch, R.M., Gustafson, K., Nieveen, N., \& Plomp, T. (pnyt.), Design Approaches and Tools in Educational and Training. Dordrecht: Kluwer Academic Publisher.

[17]. Parwati, "Pengembangan Perangkat Pembelajaran Matematika Berorientasi Open-Ended Problem Solving”, Jurnal Ilmu Pendidikan, Jilid 18, Nomor 1, Juni 2012, pp. 65-70. 